\title{
The Effect of the Principal's Academic Supervision and Leadership Style on Teachers' Performance in SD Negeri Gugus 3, Kayuagung District
}

\author{
Maimunah $^{1 *}$, Bukman Lian², Mulyadi ${ }^{2}$
}

\author{
${ }^{1} S D$ Negeri 1 Beti Jaya \\ ${ }^{2}$ Universitas PGRI Palembang \\ *Corresponding Author. Email: mayimoen70@gmail.com
}

\begin{abstract}
This research was conducted to investigate and describe the effect of the principal's academic supervision and leadership style on teachers' performance. This research was conducted by using a quantitative descriptive method, where the data were collected through questionnaires, documentation and the study of literature. The results obtained from the research indicated that there was a partial effect of academic supervision on teachers' performance, since t-count value was 9,583>t-table which was 1.988. There was a partial influence of leadership style on teacher performance because the value of tcount 11.937> ttable was 1.988. There was an effect of the principal's academic supervision and leadership style simultaneously on the performance of teachers at SD Negeri 3, Kayuagung District, because Fcount value was 80.692> FTabel 3.104. The magnitude of the effect simultaneously was $65.5 \%$ and was included in the category of high influence. There is something unique when this research is conducted on Principal Academic Supervision and Leadership Style Towards Teacher Performance. which includes abilities and skills.
\end{abstract}

Keywords: Academic Supervision, Leadership Style, Principal, Teachers’ Performance.

\section{INTRODUCTION}

Education is considered a strategic part of the development of a nation. The progress or setback of a nation is influenced by the quality of its education. With the higher quality of education, more contributions will be made for national development. One of the indicators of a country's development is the human resources (HR), which is closely related to the level of education. Highquality human resources are the results of a successful education system where it will also contribute to the capacity of the future generation.

Improving the quality of education requires highly qualified and reliable teachers because those qualities play important roles in the development of various aspects.

Performance is used as the measurement of a teacher's success or failure in carrying out educational tasks based on their responsibilities and authorities by referring to the standards of performance that have been set for a certain period. In-Law No. 14 of 2005, in article 1 paragraph (1), it is stated that teachers are professional educators whose main tasks are educating, teaching, guiding, directing, training, assessing, and evaluating students starting from their early childhood education through formal education, primary education, and secondary education [1].

Therefore, teachers' performance is one of the key factors that influence the outcome of the set education goal at a school and in a broader scope. In the reality, there has not been an effective solution given by the government to solve the problems in the education sector of Indonesia. There are always problems that occur in the implementation of education.

As a profession referred to as a role model by others as being inspiring and used as a good example by all students, the presence of 
professional teachers is highly needed in efforts to improve and upgrade the quality of education. It is impossible to carry out education and create good outcomes that meet the expectations of society and the demands of the development of the modern world without the presence of professional teachers.

In carrying out their duties, the teachers of SD Negeri 3, Kayuagung District have the same challenges and obstacles as those teaching in other places, especially in achieving the curricular goals set by the school or by the education office. There is a greater effort required to improve the competence of elementary school teachers. Lack of professionalism of teachers was revealed by Mulyasas as quoted by Faturrahman \& Sulistyorini who said that in daily education practice, there are still many teachers who make technical errors in conducting their duties. Unfortunately, their mistakes are oftentimes not realized by themselves, even many still consider them as normal and acceptable. This situation occurs because of their age, educational background or qualifications, lazy personal attitude, the distraction from activities outside the professional duties of education, and other influencing factors [2].

Referring to the Regulation of the Minister of Education of the Republic of Indonesia Number 13 of 2007 concerning Standards for Principals of Schools / Madrasahs, one of the dimensions of competence that a principal must possess is the supervision competence [3].

It applies the same for the academic supervision carried out by the principal of SD Negeri 3, Kayuagung District. From the preliminary observation conducted by the researchers, it is revealed that the principal's academic supervision of teachers is carried out by senior teachers appointed by the principal. However, since there is no follow-up from the academic supervision, the teacher does not get optimal input from the supervision activities. The senior teachers held the responsibility of inspecting the classroom teaching activities are not totally reliable since it is done in a very short duration.

Academic supervision is also directly performed by the principal towards the teachers, even though it is not carried out regularly in every semester, as the principal has various tasks and responsibilities to be accomplished other than supervision activities. As for the preliminary observations and interviews with the teachers about academic supervision, similar information is obtained. The visits organized to their target schools are often nothing more than filling in administrative data about the number of students and study groups, observing the condition of worship place, Islamic spiritual programs, and a short discussion with the teachers.

Through their authority of the supervisory duties, the principal is expected to provide advice and guidance to teachers in dealing with the curricula that experience major changes in their objectives, content, methods, and evaluation of teaching. To generate effective academic supervision, individual principals usually refer to their own style of implementation. It is also indicated that their leadership style has an impact on teachers' performance at the school.

According to Rivai, leadership style is a set of characteristics used by leaders to influence their subordinates to achieve organizational goals, while it is also possible to say that leadership style is a pattern of behavior and strategies referred by and oftentimes applied by a leader [4]. This is because the improvement of the quality of education in schools depends not only on the learning process in the form of teacher-student interaction and communication but also on the situation and the environment in which learning is taking place.

In a good situation, learning will flourish and develop well. The factors contributing to creating a good situation are the place, facility, school cultures, as well as the school atmosphere and leadership style of the school principal that contribute to well-developed classroom learnings. In a conducive situation, teachers will have a better opportunity to develop their professionalism, so they can handle the situation and solve the problems to create effective learning activities.

The leadership style adopted by the principal contributes to the results and effectiveness of the principal in organizing education in schools. Glatthorn, as quoted by Syahril, said that there is a strong correlation between the leadership style used by the principal and the overall effectiveness of the education process in schools. This means that reliable human resources are the results of the patterns or leadership styles applied in an organization which is reflected in the management of the organization. [5]

A good leadership style is reflected in the movement of the organization wheels that is comfortable, conducive, and following the 
objectives to be achieved. The leadership style applied by a leader will influence the behavior of teachers as subordinates and the working atmosphere, which will decide whether it leads to positive or negative outcomes. The rigid, monotonous, indecisive, and indifferent attitudes of the principal towards his subordinates will create an uncomfortable educational atmosphere, and it is not likely to create any progress in the learning process. Meanwhile, the flexible, dignified, fair, and attentive attitudes towards subordinates, teachers, and students will create a harmonious and comfortable educational atmosphere in learning and even create an educational achievement. Therefore, the leadership style of the principal must be adjusted to the situation, and the condition of the individuals in the school community

\section{RESEARCH METHODS}

This research was conducted in a public elementary school in Cluster 3, Kayuagung District, Ogan Komering Ilir Regency. The time of the research was from July to December 2020. The quantitative research method was selected based on scientific considerations. As it was stated by Sugiyono that "quantitative research method is based on the philosophy of positivism, used to research on a particular population or sample where sampling techniques are generally carried out randomly and research instruments are used for data collection. Data analysis is quantitative/statistical to test the hypothesis that has been established". [6]

There were 108 persons in the population, therefore 20 of them were used as the instrument trial sample and 88 others became the main sample of the study. Data were obtained through questionnaires, observation, and documentation.

\section{RESULTS AND DISCUSSION}

The classical assumption test has been applied to the data obtained from the research and it is stated that the test could be conducted by parametric analysis.

\subsection{Hypothesis Testing 1}

This test is done to determine the acceptance or rejection of the hypotheses that have been prepared. The results obtained from this test can be seen in the following table.
Table 1 Hypothesis Testing Results 1 "t-test"

\begin{tabular}{|c|c|c|c|c|c|}
\hline \multirow[b]{3}{*}{ Model } & \multirow{2}{*}{\multicolumn{2}{|c|}{$\begin{array}{l}\text { Unstandardized } \\
\text { Coefficients }\end{array}$}} & \multirow{3}{*}{\begin{tabular}{|c|}
$\begin{array}{c}\text { Standardized } \\
\text { Coefficients }\end{array}$ \\
Beta \\
\end{tabular}} & \multirow[b]{3}{*}{$t$} & \multirow[b]{3}{*}{ Sig. } \\
\hline & & & & & \\
\hline & $\mathrm{B}$ & Std. Error & & & \\
\hline \begin{tabular}{|ll}
1 & (Constant)
\end{tabular} & 22,017 & 6,077 & & 3,623 &, 000 \\
\hline $\begin{array}{l}\text { Supervisi Akadem ik } \\
\text { Kepala Sekolah }\end{array}$ & ,728 & 076 & ,719 & 9,583 & , \\
\hline
\end{tabular}

Source: processed data (October 2020)

T-count value for the principal's academic supervision variable is 9.583> $\mathrm{t}$ table which is 1.988. It means that the alternative hypothesis $(\mathrm{Ha})$ for testing hypothesis 1 is accepted. Therefore, it is stated that the principal's academic supervision has a positive and significant effect on teacher performance at SD Negeri Gugus 3, Kayuagung District.

Table 2. The Coefficient of Determinant (H1)

\begin{tabular}{|l|c|r|r|c|}
\hline Model & $\mathrm{R}$ & $\mathrm{R}$ Square & Adjusted R Square & $\begin{array}{c}\text { Std. Error of the } \\
\text { Estimate }\end{array}$ \\
\hline 1 &, $719^{9}$ &, 516 &, 511 & 2,08075 \\
\hline
\end{tabular}

Source: processed data (October 2020).

The correlation coefficient is $71.9 \%$ and is included in the strong relationship category. The determinant coefficient or the magnitude of the influence of the principal's academic supervision variable on teacher performance is $51.6 \%$, which means that it has a high influence.

\subsection{Hypothesis Testing 2}

The results obtained from this test can be seen in the following table.

Table 3. Results of Testing Hypothesis 2 "T-test"

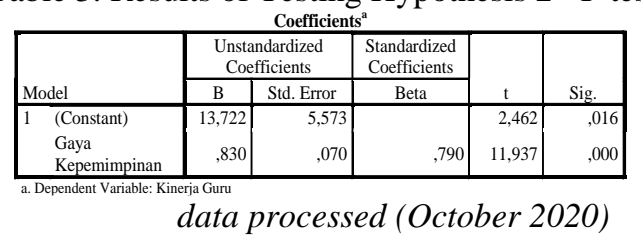

The leadership style has a positive and significant influence on the performance of teachers in SD Negeri 3, Kayuagung District.

Table 4. Determinant Coefficient (H2)

\begin{tabular}{|l|c|r|r|c|}
\hline Model & $\mathrm{R}$ & \multicolumn{1}{|c|}{ R Square } & Adjusted R Square & $\begin{array}{c}\text { Std. Error of the } \\
\text { Estimate }\end{array}$ \\
\hline 1 &, $790^{\mathrm{a}}$ &, 624 &, 619 & 1,83567 \\
\hline
\end{tabular}

Source: processed data (October 2020)

The correlation coefficient of leadership style with teacher performance is $79.0 \%$. The magnitude of the relationship belongs to the close category. The magnitude of the influence of the leadership style variable on the performance of the teachers at SD Negeri 3 Kayuagung District was 
$62.4 \%$ and included in the category of high influence.

\subsection{Hypothesis Testing 3}

The results obtained from this test can be seen in the following table.

Table 5. Test Results "Test F"

\begin{tabular}{|c|c|c|c|c|c|c|}
\hline \multicolumn{7}{|c|}{ ANOVA $^{a}$} \\
\hline \multicolumn{2}{|c|}{ Model } & $\begin{array}{l}\text { Sum of } \\
\text { Squares }\end{array}$ & df & Mean Square & $\mathrm{F}$ & Sig. \\
\hline \multirow[t]{3}{*}{\begin{tabular}{|l|l}
1 \\
\end{tabular}} & Regression & 504,301 & 2 & 252,151 & 80,692 &, $000^{6}$ \\
\hline & Residual & 265,611 & 85 & 3,125 & & \\
\hline & Total & 769,913 & 87 & & & \\
\hline
\end{tabular}

Source: processed data (October 2020)

F count of 80.692> FTabel is 3.104, which means that there is a positive and significant influence on the principal's academic supervision and leadership style simultaneously on the performance of SDN teachers in cluster 3, Kayuagung District.

Table 6. Determinant Coefficient (H3)

\begin{tabular}{|c|c|c|c|c|}
\hline \multicolumn{5}{|c|}{ Model Summary } \\
\hline Model & $\mathrm{R}$ & R Square & $\begin{array}{c}\text { Adjusted R } \\
\text { Square }\end{array}$ & $\begin{array}{l}\text { Std. Error of the } \\
\text { Estimate }\end{array}$ \\
\hline 1 &, $809^{\mathrm{a}}$ & ,655 & ,647 & 1,76772 \\
\hline
\end{tabular}

Source: processed data (October 2020)

$80.9 \%$ of both the principal's academic supervision and leadership style on the performance of teachers in SD Negeri in Cluster 3, Kayuagung District, is in the category of a close relationship. The effect of the principal's academic supervision and leadership style on the performance of teachers in SD Negeri in Cluster 3, Kayuagung District is $65.5 \%$ and is included in the category of high influence.

3.4. The effect of principal's academic supervision on teachers' performance

The effect contributed by the principal's academic supervision on teachers' performance should be a consideration for carrying out appropriate and sustainable supervision. The results of this study support several previous studies. As with the research of Mudzakir [7] and Pujianto, Arafat \& Setiawan, the results of the study conducted stated that academic supervision can have a positive impact on teachers' performance. Therefore, this study provides supports of findings and evidence for the previous research. [8]

In line with other research conducted by Hardono, Haryono \& Yusuf [9] as well as research by Aprida, Fitria \& Nurkhalis stated that academic supervision that is carried out properly by the principal will give a positive impact on teacher performance [10]. It is comparable with what Sukati stated that the implementation of supervision must be carried out properly through proper management [11]. Therefore, a school principal must be able to carry out academic supervision in a planned manner.

\subsection{The influence of leadership style on teachers' performance}

The magnitude of the relationship between the variable leadership style and teacher performance is evidence that a principal with an attractive leadership style have more opportunity to build a better relationship with staff. It is also proven that this leadership style can have a positive and significant impact on teachers' achievement in their performance.

The results of this research supports the findings of the study conducted by Guterres \& Suparta [12] and Rustamaji, Purwana \& Yohana revealed that leadership have a significant impact on teachers' performance [13].

This is one of the reasons that many researchers conducted this study, such as Sulfemi [14], Baihaqi [15], and Banani who found that a positive and significant effect occurs when leadership is well organized [16].

A similar study has also been done by Gumilar \& Munzir [17] and Mutmainah with the concept of results which emphasizes the importance of good leadership by the principal [18]. Therefore, leaders must be able to apply their leadership style effectively so that they can be accepted by their communities at school. This way, the working atmosphere at school will create more optimal outcomes.

\subsection{The effect of principal's academic supervision and leadership style on teachers' performance \\ The simultaneous testing process carried} out by researchers provides a clear understanding of the importance of implementing academic supervision along with a good leadership style. This is clearly evidenced by the high influence of these two variables when carried out simultaneously on the performance of the teachers in duties. For this reason, the principal must really understand his tasks and responsibilities well.

This study supports the results of the research obtained by Ndapaloka, Hardyanto \& 
Prihatin [19] and Astuti \& Dacholfany which revealed that when the leadership style is applied properly along with the academic supervision, it will have a significant impact on teachers' performance [20].

Similarly, to Maknun's research, this research shows that well-organized leadership and good implementation of academic supervision result in a positive and significant effect on teachers' performance [21]. Therefore, it is important for school principals to understand well their main responsibilities and roles to accomplish great outcomes and achievements.

\section{CONCLUSION}

Based on the results of the study and the discussion of the research findings, it is concluded that 1) the academic supervision of the principal

\section{REFERENCES}

[1] Government of the Republic of Indonesia. (2005). Law Number 14 of 2005 concerning Teachers and Lecturers. Jakarta: Government of the Republic of Indonesia.

[2] Faturrahman, \& Sulistyorini, R. (2015). Supervisi pendidikan dalam pengembangan Proses Pengajaran. Bandung: Refika Aditama.

[3] Ministry of National Education. (2007). Regulation of the Minister of National Education Number 13 of 2007 concerning Standards for School/ Madrasah Principals. Jakarta: Ministry of National Education.

[4] Rivai, V. (2014). Manajemen Sumber Daya Manusia untuk Perusahaan. Jakarta: Raja Grafindo Persada.

[5] Syahril, B. (2013). Pengaruh Gaya Kepemimpinan Kepala Sekolah, Sikap Guru dan Disiplin Guru Terhadap Kinerja Guru SMA Negeri di Kota Manna Bengkulu Selatan. Bengkulu: Universitas Bengkulu.

[6] Sugiyono. (2017). Metode Penelitian Kualitatif, Kuantitatif dan $R \& D$. Bandung: Alfabeta.

[7] Mudzakir, D. (2016). Implementasi Supervisi Manajerial Dan Akademik Pengawas Dalam Meningkatkan Kinerja Guru Pendidikan Agama Islam Madrasah Ibtidayah. Studia Didaktika, 10(2), 33-47. has a positive and significant effect on the teachers' performance; 2) The leadership style has a positive and significant effect on teachers' performance; 3) Principal's academic supervision and leadership style together have a positive and significant effect on the teachers' performance at SD Negeri 3, Kayuagung District. The effect simultaneously is sixty-five point five percent, which is considered to be in the category of a high level of influence.

\section{ACKNOWLEDGMENT}

The researchers would like to thank all parties contributing to this research, especially the leader and staffs at the PGRI Palembang University and the Education Office of Ogan Komering Ilir Regency.

[8] Pujianto, P., Arafat, Y., \& Setiawan, A. (2020). Pengaruh Supervisi Akademik Kepala Sekolah dan Lingkungan Kerja Terhadap Kinerja Guru Sekolah Dasar Negeri Air Salek. Journal of Education Research, 1(2), 106-113.

[9] Hardono, H., Haryono, H., \& Yusuf, A. (2017). Kepemimpinan Kepala Sekolah, Supervisi Akademik, dan Motivasi Kerja dalam Meningkatkan Kinerja Guru. Educational Management, 6(1), 26-33.

[10] Aprida, Y., Fitria, H., \& Nurkhalis, N. (2020). Pengaruh supervisi kepala sekolah dan motivasi kerja guru terhadap kinerja guru. Journal of Education Research, volume 1 issues 2, 160-164.

[11] Sukatin. (2016). Manajemen supervisi dalam pendidikan (studi kasus di MAN Model Jambi). Hikmah: Jurnal Pendidikan Islam, 5(2), 221-240.

[12] Guterres, L. A., \& Suparta, W. (2016). Pengaruh gaya kepemimpinan dan motivasi kerja terhadap kinerja guru. e-Jurnal Ekonomi dan Bisnis Universitas Udayana, 5(3).

[13] Rustamaji, A. C., Purwana, D., \& Yohana, C. (2017). Gaya Kepemimpinan Transformasional Kepala Sekolah dan Kinerja Guru SMK Swasta di Jakarta Timur. Jurnal Pendidikan Ekonomi dan Bisnis, 5(2), 148-161.

[14] Sulfemi, W. B. (2020). Pengaruh rasa percaya diri dan gaya kepemimpinan kepala 
sekolah terhadap kinerja guru. Nidhomul Haq: Jurnal Manajemen Pendidikan Islam, 5(2), 157-179.

[15] Baihaqi, M. I. (2015). Pengaruh gaya kepemimpinan kepala sekolah dan motivasi kerja terhadap kinerja guru di MA Ma'arif Selorejo Blitar. Konstruktivisme, 7(2), 97106.

[16] Banani, M. T. (2017). Pengaruh Kepemimpinan Kepala Sekolah terhadap Kompetensi Guru dalam Mewujudkan Efektivitas Pembelajaran. Jurnal Pendidikan UNIGA, 11(1).

[17] Gumilar, G. G., \& Munzir, T. (2018). Pengaruh gaya kepemimpinan kepala sekolah terhadap kinerja guru SMA Global Indo-Asia Batam. Jurnal Dimensi, 7(2), 255-266.

[18] Mutmainah. (2016). Pengaruh kepemimpinan kepala sekolah dan profesionalitas guru terhadap kinerja guru SMK Negeri 1 Tepus. Yogyakarta: Universitas Negeri Yogyakarta.

[19] Ndapaloka, V., Hardyanto, W., \& Prihatin, T. (2016). Pengaruh supervisi akademik pengawas dan kepemimpinan kepala sekolah melalui motivasi berprestasi sebagai mediasi terhadap kinerja guru SMK Negeri di Kabupaten Ende. Educational Management, $5(1), 42-54$.

[20] Astuti, R., \& Dacholfany, M. (2016). Pengaruh Supervisi Pengawas Sekolah Dan Kepemimpinan Kepala Sekolah Terhadap Kinerja Guru Smp Di Kota Metro Lampung. Jurnal Lentera Pendidikan Pusat Penelitian LPPM UM Metro, 1(2), 204-217.

[21] Maknun, L. L. (2019). Pengaruh Gaya Kepemimpinan Dan Supervisi Akademik Kepala Sekolah Terhadap Kinerja Guru Sekolah Dasar Di Gugus Dewi Sartika Kecamatan Adiwerna Kabupaten Tegal. Semarang: Universitas Negeri Semarang. 